\title{
ИНГИБИТОРНЫЕ И ПРОТИВООПУХОЛЕВЫЕ СВОЙСТВА 7-МЕТИЛГУАНИНА
}

\author{
Д.К.Нилов \\ НИИ физико-химической биологии имени А.Н. Белозерского, \\ Московский государственный университет имени М.В. Ломоносова, \\ 119991, Россия, Москва, Ленинские горы, д. 1, стр. 40.
}

DOI: 10.19163/MedChemRussia2021-2021-148

E-mail:nilovdm@gmail.com

Природное соединение 7-метилгуанин (7-МГ) подавляет активность ферментов поли(АДФ-рибозо)полимеразы и тРНК-гуанинтрансгликозилазы, которые важны для пролиферации раковых клеток [1-4]. В настоящее время активно исследуются ингибиторные и противоопухолевые свойства 7-МГ in vitro, in vivo, а также методами компьютерного моделирования.

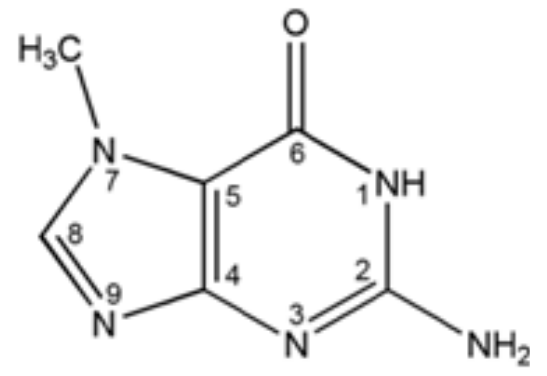

В докладе будут представлены результаты моделирования взаимодействия 7-МГсполи(АДФ-рибозо)полимеразой итРНК-гуанинтрансгликозилазой, результаты тестирования цитотоксического действия 7-МГ в отношении линий раковых клеток (в монорежиме и в комбинации с цисплатином и доксорубицином), а также предварительные данные по противоопухолевой активности in vivo, полученные при пероральном введении 7-МГ мышам с перевитой опухолью. Кроме того, будут представлены данные о способности 7-МГ быстро проникать в клетку и подавлять синтез поли(АДФ-рибозы).

Работа поддержана Российским научным фондом (грант № 19-74-10072).

\section{Литература}

[1] G. Manasaryan, D. Suplatov, S. Pushkarev, V. Drobot, A. Kuimov, V. Švedas, and D. Nilov, Cancers (Basel). 2021, 13, 1201.

[2] D. Nilov, N. Maluchenko, T. Kurgina, S. Pushkarev, A. Lys, M. Kutuzov, N. Gerasimova, A. Feofanov, V. Švedas, O. Lavrik, and V.M. Studitsky, Int. J. Mol. Sci. 2020, 21, 2159.

[3] J. Zhang, R. Lu, Y. Zhang, Ż. Matuszek, W. Zhang, Y. Xia, T. Pan, and J. Sun, Cancers. 2020, 12, 628.

[4] W.R. Farkas, K.B. Jacobson, and Katze J.R., Biochim. Biophys. Acta. 1984, 781, 64-75.

$$
-148-
$$

